岡山県下に発生せる流行性肝炎特に その病原体に関する研究

\author{
第 三 編 \\ 経口威染に関する知見補遗 \\ 岡山大学医学部微生物学敉室 (主任: 村上 栄敉授) \\ 大賀 寿 朗
}

[昭和 32 年 3 月 26 日受稿]

腥言

岡山県下飞発生した流行性肝炎は，昭和27 年以来県下全地域飞蓝延波及して增加の一途 を辿り，終熄する迄に至らぬまま次第に慢性 旰炎の傾向を示して末だに発生は絶えぬ現況 である.その疫学的観察は小坂り，石田2)等 により広讯に行われている，その内特に感染 経路に就ての所見では，“Fecal oral Route” は先ら゙挙げられる径路であると推測している.

既飞先人によつて消化器感染3345)の可能性 は唱えられた所であり，污染された水及び食 物が先つ推定される事は，夫《の地域に於け る流行は極めて滛浸度が強く，かつ分布が広 い地域飞迅速飞移る事，又家族内感染が極め て多い事例等より推測された。

著者は流行性肝炎の発生が, 前述の消化器 䅠染によるすのと推定のるとに，村上等の分 離した病毒を用い，経口感染の成立するかど うかを奏験的にマウスを用いて行つた。 その 結果マウスに於ける経口感染は, 容易飞而す 確実に行われる事実を知ると共に，累代移植 るまた容易な事実を知つた，更に引続いて胃 及び腸内に於ける病毒の運命を追究した，本 編に於ては主としてウイルス血症に関する笂 験を行つたのでその所見に就て述へる.

\section{実跌材料及ひ方法}

供試病毒：実験に使用した分離病毒は，前 回の実験と同様にマウスに累代を継続してい
るすのを使用した，石原，小川の両株であり 共に睬化蹁卵で累代し，マウスに接種する事 により定型的な病変を惹起する病毒株であ る.

ウイルス血症の検討方法：䍜患マウス肝 臟を多数集め pool した後科量, 10 倍量の食 塩水 (pH 7.6) を添加して Homogenizer K 装して均等な乳郕とし，3000 r. p. m. 10 分遠 心沈澱して上清を病毒含有粗乳刘として使用 した。 この病毒粗乳郕を前回と同様に経口的 に投与した後，逐次心血を採取して新しく準 備したマウスの腹燃内に接種を行い，14日後 に屠殺, 型の如く满理標本を作り，その病理 学的検索を行い感染の程度を検討した。

飽和試験：Wildführ の原法 $\left.(1953)^{6}\right)$ 飞做

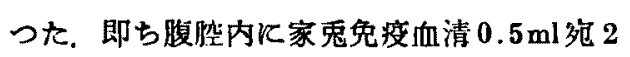
回に互り皮下に接種しておき，4時間後に於 て生病毒 $0.3 \mathrm{ml}$ 宛 (10-2 稀釈を用いた) 経口 的にビニール製の小管により自然に胃内に注 入させ, 更に14日経過した後夫々の歲器をと り病理学的阶見を検討した。

\section{実 験 成}

前回に做い経口的にビニール製の小管を用 い, 病毒含有粗乳剂を胃内に投与すると感染 が惹起する事実，殊に胃及び腸に於ける将毒 が如何なる経造を辿るかとの疑問は既に第二 編飞記載した如く，冒腸飞於て相等度の損賃 を蒙り減毒されるが，一部は腸壁より吸收さ れると推測すべき結果を得た，本編に於ては 
病毒が胃内に注入されてから腸より吸收され， 血行又は淋巴行を介して門脈を経て肝缄に定 着增殖する過程に於ける第一次的のウイル ス血症が推測され，更に肝臟飞定着後の第二 次的ウイルス血症も予想されるので，光等 のウイルス血症の発現状態を知るために血 液内ウイルスの消長を追究した（第 1 表).

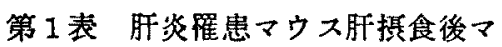
ウスのウイルス血症

\begin{tabular}{|c|c|c|c|c|c|c|}
\hline 時日 & - 株種 & 石 & 原 株 & 小 & $川$ & 株 \\
\hline 3 & 時 間 & & - & & $\perp$ & \\
\hline 5 旺 & 時 間 & & - & & + & \\
\hline 7 & 時 間 & & - & & - & \\
\hline 12 & 時 間 & & - & & - & \\
\hline 24 & 時 間 & & $\perp$ & & $\perp$ & \\
\hline 2 & 日 & & - & & + & \\
\hline 3 & 日 & & $\perp$ & & + & \\
\hline 4 & 日 & & + & & + & \\
\hline 5 & 日 & & $\perp$ & & 1 & \\
\hline 6 & 日 & & $\perp$ & & $H$ & \\
\hline 7 & 日 & & + & & + & \\
\hline 10 & 日 & & $\perp$ & & + & \\
\hline 12 & 日 & & $H$ & & 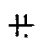 & \\
\hline 16 & 日 & & \# & & $\#$ & \\
\hline 20 & 日 & & + & & + & \\
\hline
\end{tabular}

㖣。 i) $(H)(H)(+-)(+)(\perp)(-)$ 病変の程度 を示す。

表示した如く経口的に病毒を胃内に注入後， 心滕血液を心䏮穿制により血液の凝固を防ぎ 棌取し，新しく準備したマウスに接種した。 その間所定の時間を括き同棣な操作を反復し た結果, 石原, 小川両株共飞 $3 \sim 24$ 時間飞於 ける所見では, 初の 3，5，7，12 時間までは 殆んど病理所見は認められないが，小川株で は 3 及び 5 時間のるのでは軽度の病変を認め た。 濔後両病毒間に多少の差はあるが，1〜 5日のbのでは軽度な病変が見られ，略定型 的な病変は小川株飞於ては 6 日, 石原侏飞於 ては7日のすので見られ，その後著者の检じ た20日迄略確奉な所見を示した。而して本获 毒は非経口的に接種した場合のマウスに於け る定型的の所見は，6〜7日以後認められ る事告微すれば，流向中の病毒が5〜7日
から多くなる事と平行関係が成立つといえ る。

肝瀻に於ける6 日前後の病理所見は，星細 胞の肥大及び増殖が現われ，特に肝細胞の配 列の乱れた部分が著明である。同時に䏦細胞 解離して原形睤溷濁不透明化して核が濃縮さ れたもの，又は染色性を失つたすのも認めら れた。細胞浸潤の発現は一部のグリソン氏鞘 に小円形細胞が見られる以外は軽度であり， 垻死巣周囲を単球に囲まれた特異的な所見は 末た発現していない。雨後次第に病理学的所 見は高度な様相を呈するに至り，14日後飞於 ては肝細胞の変性すまた空胞性若しくは顆粒 性となり，先飞述へた練胞漫潤も門脈域若し くは小葉内に著明に認められる。この時の細 胞は淋巴粎細胞浸潤が主であるが，単球を含 む場合が少くなく中性多核白血球を屡々散見 せられる。 また㙵死栄を囲む単球が定型的に 発現して来る等，之等の所見が多種多様に混 合して奏に多彩な满変を呈するのが羿められ る。この時期は大略14日前後である事実は, 一応の本病毒の示す病変の頂点を示すすので あろ5. 而して倉内7)の指摘した所謂慢性化 の所見は，斯かる14日前後の病変が此後長期 間に互り観察されるるので本病盇の特徽とも いえる.

次に経口的に病毒を胃内に汸入し，一定時 間後に心血を採取し新しく染備したマウスに 接種した後, 元の感染マウスの病理学的所見 を検した。 この梌索は最初経口的に投与した 病毒がマウスに確实な感染を惹起していたか 何うかを確めるためのるのである，この実験 の結果は，等しく6 -7 日飞於て肝臟の所見 が略定型的炲り，逐次感染听見は進展して 行く事を明瞭江している（第 2,3 表）.

上記の成績から胃内経口的飞病毒が注入 された後，一定時期を経て肝睵に定着增殖し 第二次的ウイルス血症を莣起する過程に於 ては，一応の結末を得たと推測されるが，次 と之等の場合病等の分析状態を追究した. そ

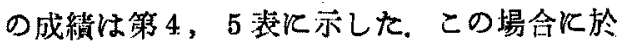
ける稀釈実験では，経口投与の凡そ14日前後 
第 2 表 肝炎䍜患マウス肝摄食後時間的推移に於ける肝肺满理所見

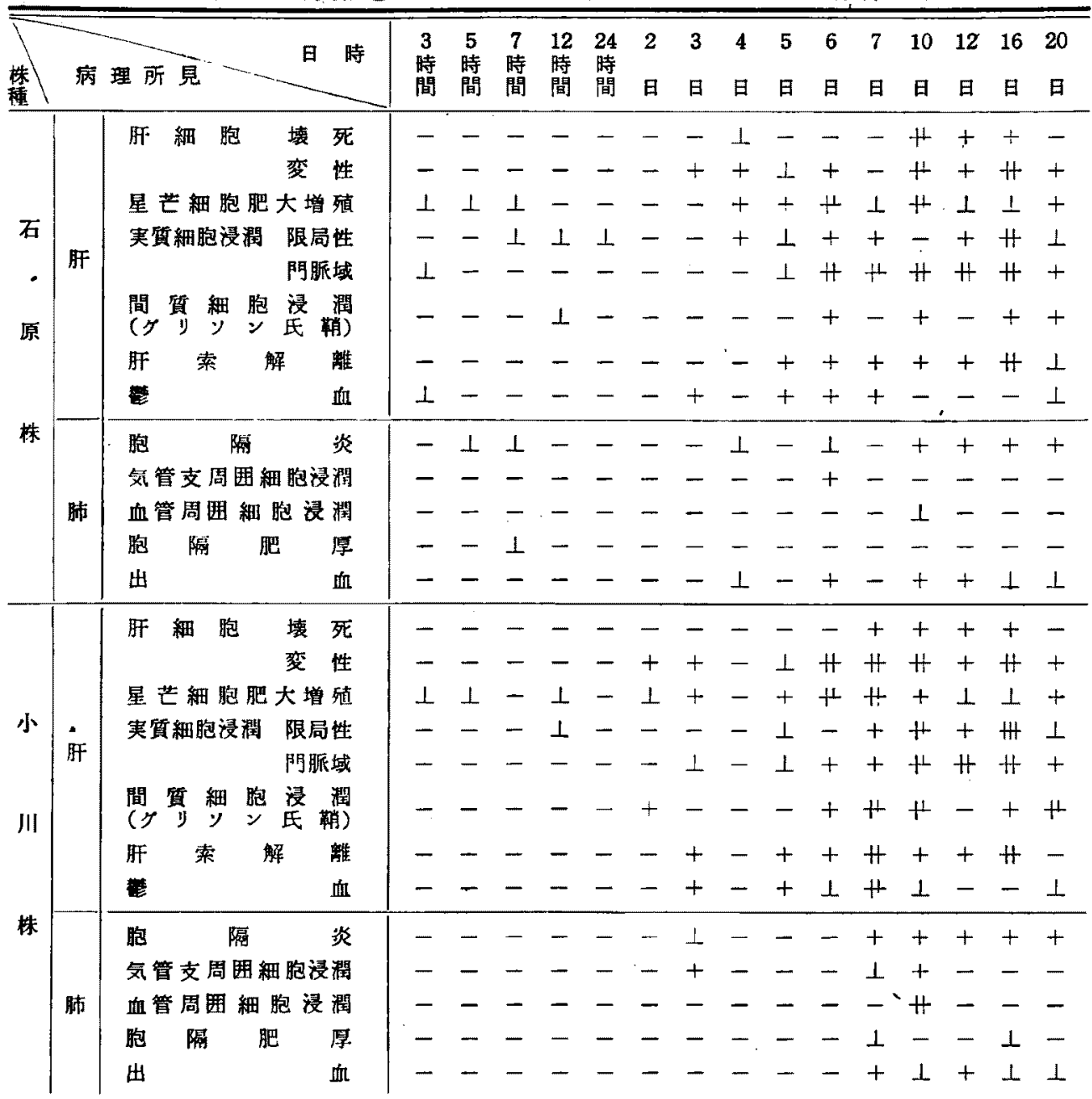

第 3 装 肝炎罹患マウス肝掑食後時間的推移に於ける各缄器所見

\begin{tabular}{|c|c|c|c|c|c|c|c|c|c|c|c|c|c|c|c|c|}
\hline 株 & 時間 & $\begin{array}{c}3 \\
\text { 時 } \\
\text { 間 }\end{array}$ & $\begin{array}{c}5 \\
\text { 時 } \\
\text { 間 }\end{array}$ & $\begin{array}{c}7 \\
\text { 時 } \\
\text { 間 }\end{array}$ & $\begin{array}{l}12 \\
\text { 時 } \\
\text { 間 }\end{array}$ & $\begin{array}{l}24 \\
\text { 㭙 } \\
\text { 間 }\end{array}$ & 日 & $\begin{array}{l}3 \\
\text { 日 }\end{array}$ & $\begin{array}{l}4 \\
\text { 日 }\end{array}$ & 日 & 日 & 日 & 10 & 12 & 16 & 20 \\
\hline \multirow{2}{*}{ 石 } & 肝 & - & - & - & - & - & - & $\perp$ & + & + & + & + & $H$ & + & H & H \\
\hline & 肺 & - & - & - & - & - & - & - & $\perp$ & - & $\perp$ & $\perp$ & + & + & + & + \\
\hline \multirow{2}{*}{ 原 } & 脑 & - & - & - & - & - & - & - & - & - & - & $\perp$ & $\perp$ & $\perp$ & - & - \\
\hline & 脾 & - & - & - & - & - & - & - & - & - & + & $\perp$ & $\perp$ & $\perp$ & - & $\perp$ \\
\hline \multirow[t]{2}{*}{ 株 } & 照 & - & - & - & - & - & - & - & - & - & - & - & - & $\perp$ & - & + \\
\hline & 胆 & - & - & - & $\rightarrow$ & - & - & - & - & - & - & - & - & - & - & - \\
\hline \multirow{2}{*}{ 小 } & 肝 & - & - & $\perp$ & - & $\perp$ & - & $H$ & $\perp$ & + & $H$ & H & + & + & H & + \\
\hline & 肺 & - & - & - & - & + & - & + & $\perp$ & - & $\perp$ & 1 & $\perp$ & + & + & + \\
\hline \multirow{2}{*}{ 川 } & 畩 & - & - & - & - & - & - & - & - & - & $\perp$ & - & $\perp$ & $\perp$ & - & - \\
\hline & 脾 & - & - & - & - & - & - & - & - & - & $\perp$ & $\perp$ & $\perp$ & $\perp$ & $\perp$ & $\perp$ \\
\hline \multirow[t]{2}{*}{ 株 } & 筒 & - & - & - & - & - & $T$ & - & - & - & - & - & + & - & - & + \\
\hline & 晹 & - & - & - & - & - & - & - & - & - & - & $-^{\circ}$ & - & - & - & - \\
\hline
\end{tabular}

䧳。 i) $(H) \sim(-)$ 病变の程度を示す。 
第 4 表 経口感染時の体内分布

\begin{tabular}{|c|c|c|c|c|c|}
\hline \multirow{2}{*}{ 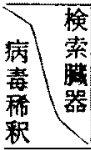 } & 脸 & 肝 & 肺 & 脾 & 留 \\
\hline & 肝肺脳 & 朋 肺 & 肝 肺 & 肝肺 & 肝肺 \\
\hline $10-2$ & ++- & +1 & ++ & +- & +- \\
\hline $10^{-3}$ & $+1-$ & +1 & ++ & +- & ++ \\
\hline $10^{-4}$ & $+\perp-$ & $H+$ & $+1+$ & +1 & $+t$ \\
\hline $10^{-5}$ & $+1-$ & $H+$ & $H+$ & +- & +1 \\
\hline $10^{-6}$ & $+1-$ & $H \perp$ & ++ & $+\perp$ & +1 \\
\hline $10^{-7}$ & $1--$ & +1 & $1-$ & +- & +- \\
\hline $10^{-8}$ & -- & +1 & ++ & $\perp-$ & - \\
\hline $10^{-9}$ & $\perp \perp-$ & +1 & $\perp \perp$ & $\perp-$ & +1 \\
\hline
\end{tabular}

註. i) $(H)(+)(\perp)(-)$ 病変の程度を示す。 ii) 病毒株は小川株
の各臟器を用いたので，病毒の分布がある程 度推定される時期である。即ち各臓器別飞見 るに朋，肺に病毒は最も多く，次いで腎，脾， 脳の順に病毒力は少いと考克られる。

病毒の経口感染がよく成立し，病理学的所 見が比較的安定している事実を知り得たので， 感染径路に経口感染を選び，Wildführ が血 清学的に型別試験を行つた“Absättigungsversuch”を応用して中和反応を試みた。こ の実験に就ては藤原到の報告した方法を踏襲 した. 即ち家鬼免度血清を用いてマウスを処 置し，4時間後に生病毒にて攻慗し，マウス の示す病理所見により中和の有無を検討した。 元来この飽和試験では，ある場合にはよく中

第 5 表 経口感染時体内分布（肝，肺病理所見）

\begin{tabular}{|c|c|c|c|c|c|c|c|c|c|c|c|c|c|c|c|c|c|}
\hline \multirow{2}{*}{\multicolumn{3}{|c|}{ 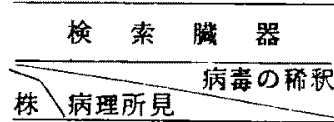 }} & \multicolumn{3}{|c|}{ 脳 } & \multicolumn{3}{|c|}{ 胿 } & \multicolumn{3}{|c|}{ 胡 } & \multicolumn{3}{|c|}{ 脾 } & \multicolumn{3}{|c|}{ 笲 } \\
\hline & & & $10^{-4}$ & $10^{-6}$ & $10-9$ & $10^{-4}$ & $10^{-6}$ & $10^{-9}$ & $10^{-4}$ & $10^{-6}$ & $10^{-9}$ & $10^{-4}$ & $10-6$ & $10^{-9}$ & $10^{-4}$ & $10^{-6}$ & $10-9$ \\
\hline \multirow{6}{*}{ 小 } & \multirow{8}{*}{ 肝 } & 肝細胞 唗 死 & - & - & - & H & + & - & + & - & - & - & - & - & - & $-{ }^{*}$ & - \\
\hline & & 塗 些 & + & + & - & + & + & - & + & + & - & + & + & - & + & + & + \\
\hline & & 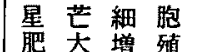 & + & $\mu^{1}$ & $\perp$ & Ht & $H$ & + & + & + & + & + & $\perp$ & + & + & + & + \\
\hline & & $\begin{array}{r}\text { 赛啠練胞浸閏 } \\
\text { 限局性 }\end{array}$ & - & + & + & + & + & - & + & + & + & + & $\perp$ & - & H & $\perp$ & + \\
\hline & & 門脈域 & + & + & + & + & + & - & + & + & - & - & $\perp$ & $\dot{-}$ & $\perp$ & + & + \\
\hline & & 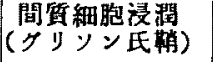 & - & + & - & - & + & - & + & - & - & - & $\perp$ & - & + & + & - \\
\hline 川 & & 肝 索 解 蜼 & - & - & $\perp$ & - & + & - & - & - & + & - & + & + & - & - & - \\
\hline & & 睡 & - & - & + & + & - & + & + & - & - & - & $\perp$ & + & - & - & + \\
\hline \multirow{5}{*}{ 株 } & \multirow{5}{*}{ 肺 } & 胞 隔 炎 & + & $\perp$ & $\perp$ & - & + & $\perp$ & + & + & + & - & $\perp$ & $\perp$ & + & $\perp$ & $\perp$ \\
\hline & & $\begin{array}{l}\text { 氮管支周贯 } \\
\text { 細胞 浸娍 }\end{array}$ & - & - & $\perp$ & 1 & + & $\perp$ & - & - & - & - & - & - & + & + & - \\
\hline & & 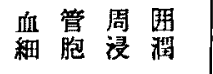 & - & $\perp$ & $\perp$ & $\perp$ & - & - & - & - & - & $\perp$ & - & - & + & - & + \\
\hline & & 胞 隔肥 厚 & $\perp$ & $\perp$ & $\perp$ & $\perp$ & - & $\perp$ & + & - & - & - & $\perp$ & - & $\perp$ & - & - \\
\hline & & 血 & - & - & - & $\perp$ & + & $\perp$ & + & - & - & - & - & - & - & - & - \\
\hline
\end{tabular}

詰: i） $(+1) \sim(-)$ 病変の程度を示す。

和能を推測すべき所見も見得るが，免疫血清 の抗体佂が低い場合は良結果が得られない事 す少くない。

その成績に就て見るに（第 6.7 表），使用 した免疫家鬼血消の免疫力価は高いるのであ つたが，㨏理所見の上から多少中和の傾向が 認められたに䧟ぎなかつた。兰はマウス体内
第 6 表 経口感染時の“Absättigungsversuch”

\begin{tabular}{|c|c|c|c|c|c|c|c|c|}
\hline 病㪇の稀彩 & $10-2$ & $10^{-3}$ & $10^{-4}$ & $10^{-5}$ & $10-6$ & $10-7$ & $10-8$ & $10-9$ \\
\hline 経口接程 & $\perp$ & $\perp$ & + & $\perp$ & + & + & + & \\
\hline 対 照 & + & + & $H$ & $H$ & + & + & H & $H$ \\
\hline
\end{tabular}

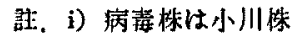

ii）経口注入性夫々稀稂病毒 $0.3 \mathrm{ml}$ 使用

iii) $(+)(+)(\perp)$ 病変の程度を示す。 
第 7 表 飽和試験 (肝, 肺病理所見)

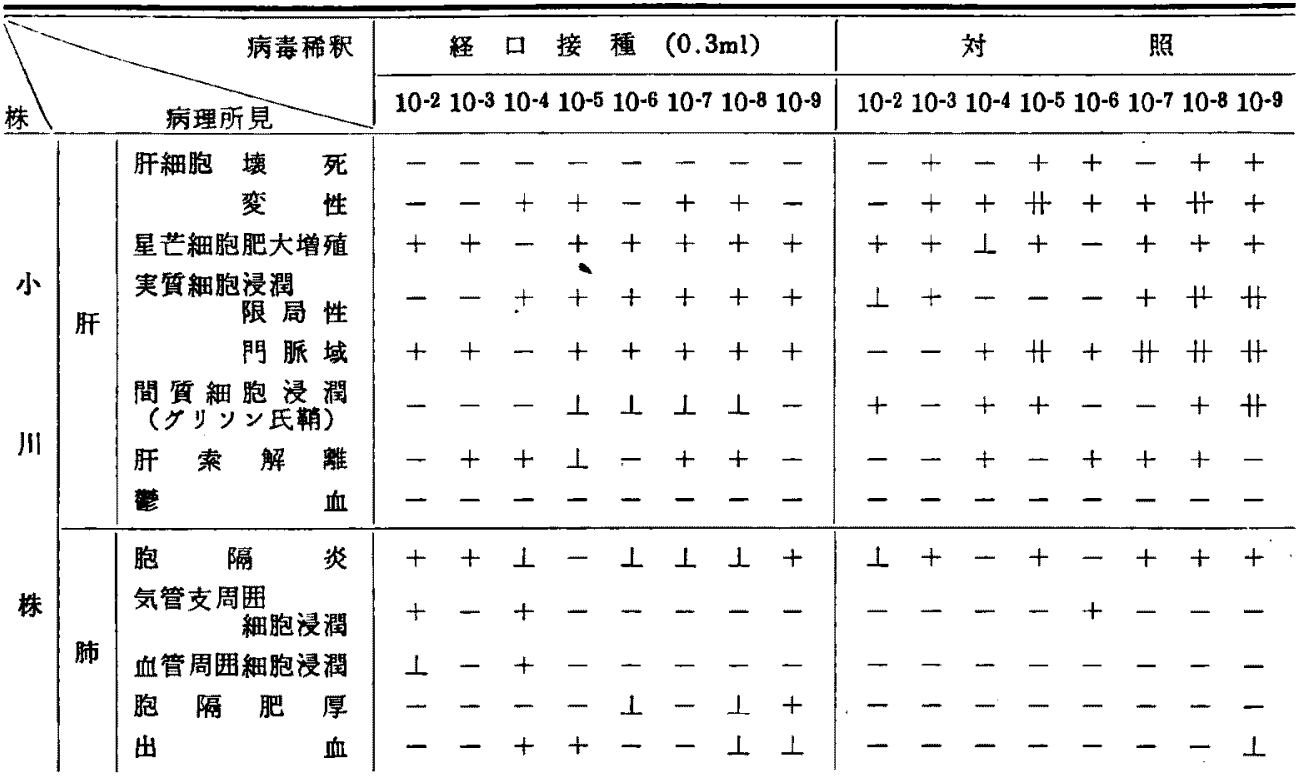

註。 i) $($ H) ( ( ) 病变の程度を示す。

そ於ける中和が完全に行われなかつた事を意 味するるので, 生病毒の稀釈, 純化或は低温 度に於ける両者の接触特間等考虑すへき問題 を示唆していると考えられる。

更に著者は小川株を用いて経口感染を行い， 14，50及び65日後に於ける病理変化を検へた (第 8 表)．即ち病毒の経口投与に上る感染は，
6〜7日で略確実な病理所見として認められ， 14日前後で特有の塭死单を囲む単球が現われ るに至る事は既汇述べたが，50日，65日の所 見でも病変が著しく進行したと思われない. 慢性化の経過は，更䞍時間の観察を必要と するすのと考えられるが，著者の成績から推 測すれば，慢性化の状態は感染径路殊に経口

第 8 表 経口感染時慢性化の際の肝, 肺病理所見

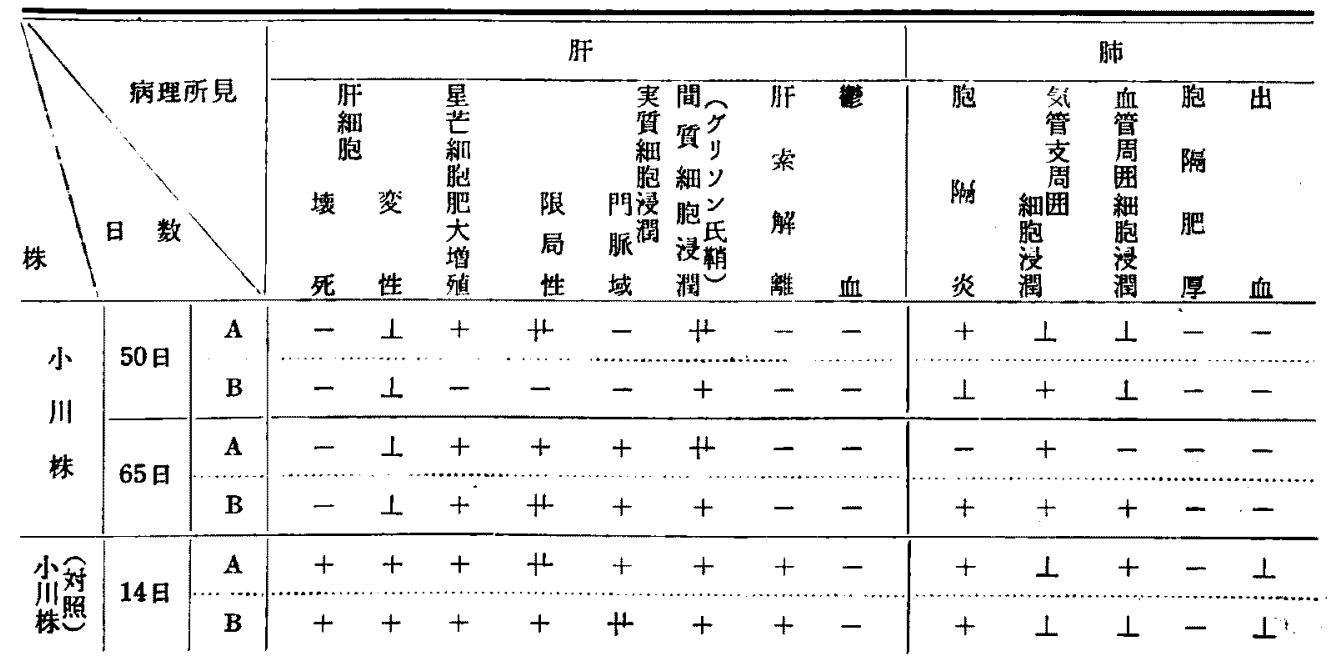

註. i) $(H)(+)( \pm)(-)$ 病変の程度を示士。 
感染によつて特有な病変を示すすのでなく， 腹腔内感染の場合》と比較して大差なき病理 所見として見られるるのと推測された。

\section{総括及び考察}

流行性肝炎患者上り分離された病毒を用い て实駼を行い，著者は既飞病毒を罢内注入 すると腸壁より吸收され感染が起り，各㖪器 に定着增殖する事を知つたので，本絋に於て は経口的に注入された病毒の連命を知る意味 から，ウ1ルス血症に就て夷験を行うと共 飞，その後に於ける将毒の分布，更に経口感 染による飽和試験及び慢性化の経過に就て, 病理組織学的飞追究し㭘討した。

経口的に病毒を投与した後，一定時間後心 血を採取する事により，血液中のウイルス 血症を検したが，1〜5日のものでは軽度の 病変㵝過さいが，定型的な病変が $6 \sim 7$ 日 に於て見られる粐になり，20日迄の契娩にて 略確実な所見を示した，又時間的に逐次屠殺 したマウスの病理所見にても，6〜7日頃よ り肝腷飞略定型的な所見を示し，14日前後を 最高として後に引続く様相が見られた。な括 その時期江於ける体内膤器内の病毒の分布は, 肝，肺，留，脾，脳の順飞病毒力が存する所 見を見た。等の実験から肝炎患者よりの分 離病毒は，明か江向肝性ウイルスであると の推定が確実となつた，而子真の意味の肝炎 病毒と同様に，経口感染が容易飞而す確実に 成立する証明とるなる所見を得た，な拓経口 感染の際の肝傤に於ける第二欠うイルス血 症は確実澺起するるのであるが，著者の推 定した如くその ウイルス血症に対しても多 少の疑問は残つているが，前相した経䧟を迪 るのが大略本米の形であるろと推察されるの である.

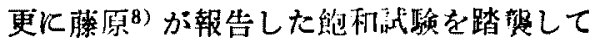
経口感染せる場合のるのについて枮したが,

\section{文}

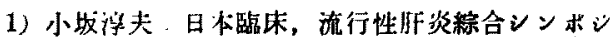
ウム、Vol. 12, No. 133，䀡和29年10月。
病理所見の上から多少中和の傾向が認められ たが，之は未だマウス体内に於ける中和が完 全に行われなかつた事を意味し，今後更て種 々考虑すべき問題を示唆していると思われる。

更に又50日，65日経過せる場合の所見子観 察したが，病変が著しく進行したとも思われ ず，元来分離病毒が，目内7) の指摘している 粎に慢性化の経過を経る傾向が強いので，著 者の急性の経過を経た場合の推測が一般に行 われるのが普通としてる，その後に於ける ウイルス血症が如何に移行し推移して行くも のか全く予想されないが，実験の結果から見 て病瑇接種後14日前後に始つたウイルス血 症が，肝淢化於ける病毒の增殖後渐次增强さ れ，而る持続されるるのと観察するより外化 は解釈に苦しも所である5。

結論

県下に発生した流行性肝炎患者より分離さ れた病毒を用いて，第一編より引続き経口感 染に於ける分離病毒の感染及び累代，更飞感 染の機転及びウイルス血症に就て，主として その病理学的所見より追及して次の結論を得 た.

1）病毒を胃内に注入した場合，病毒は先 ず肝臟飞定着增殖を行 5 と共に，略之と平行 してウイルス血症を発来し，凡そ病毒の体内 侵入後14日前後に於てウイルス血症の頂点が 見られるものであるらとい5事は, 病毒の示 与病理学的所見及び病毒の体内分布等より示 唆された。

2）経口感染に於ける本来の感染の機転は， 大体著者の推定した結果を得たが，病毒が慢 性の経過を辿つた場合の感染及びウイルス血 症に就てはな技疑問がある。

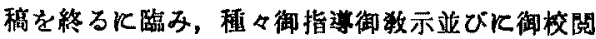
の当を睗つた恩仰村上栄教授飞澡其の懒意を表する。

献

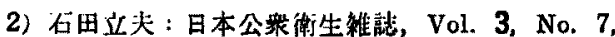
昭和31年 7 月。 
3) Findlay, G.M. and Willcox, R. R. : Lancet ii 594, 1945.

4) Van Rooyen: Virus Diseases of man, $P$. 1164, 1948.

5) Neefe, J. R. and Stokes, J. Jr. : J. A. M. A.
128, 1063, 1945.

6) Wildführ : Zeitschr. f. d. ges. innere Med. 573, 1953.

7) 会内嘉人：末発表.

8) 藤原清 : 岡医誌第69巻 4 号, 1957 .

\title{
Studies on the Pathogenic Agent of Infectious Hepatitis In Okayama Prefecture
}

\section{III : The supplemental studies on the infection by the alimentary canal}

By

\section{Toshio Ohga}

\author{
Department of Microbiology, Okayama University Medical School \\ (Director: Professor Dr. Sakae Murakami)
}

Following the studies in part I and II, the author studied the establishment of infection by the oral administration of virus, the mechanism of infection, and viremia. These were investigated chiefly by the observation of pathological changes of the tested mice. The results were as foliows :

1) The investigation of the pathological changes and the distribution of virus in the animal body revealed that the fixation and multiplication of the virus occurred in the liver, and, in parallel with these, the viremia went and reached the maximum around the 14th day after the injection of virus into the stomach.

2) As for the essential mechanism of the alimentary infection, the previously infered results were obtained. In case of the chronic infectious course, however, there remained some questionable points as to the mechanism of the establishment of infection and viremia. 